\title{
(DIS)CLOSED: TABERNACLE ALTARPIECES IN THE RHINELAND
}

\author{
(DES)VELADO: RETABLOS-TABERNÁCULO EN RENANIA
}

\author{
Pavla Ralcheva \\ Universität zu Köln \\ pavla.ralcheva@gmx.de \\ https://orcid.org/oooo-0002-4777-5810
}

Received: 08/10/2019 - Accepted: I4/OI/2020

\begin{abstract}
Most of the tabernacle altarpieces preserved throughout Europe are fragmented, overpainted, and reconstructed, thus impeding a closer analysis of their image program. A detailed study of the earliest fully preserved representatives of this altarpiece type originating from the Lower and Middle Rhine as well as some other little-known late medieval examples from this region will cast some light upon topics such as the construction and evolution of the form as well as the iconography and media used in its creation and its possible impact on the spectator. This study concentrates on a small group of almost completely preserved tabernacle altarpieces, which allows detailed observation of their all-around design. This enables an examination of the ensemble of sculpture and painting, the strategies of emphasizing the venerated sculpture as well as points of reference between the images on the interior and on the exterior. Another aspect of this survey addresses questions regarding the different ways an altar could be adjusted and displayed spatially (with the wings fully open or partially closed) and the perception of these objects, most of which are designed to be viewed from all sides - issues that have received little attention in the research on tabernacle altarpieces so far. The results of this brief survey will also serve as groundwork for answering questions about the long durability of the tabernacle altarpieces alongside new forms such as winged altarpieces.
\end{abstract}

\section{Keywords}

Tabernacle altarpiece, altar, Rhineland, Germany, sculpture, painting, Later Middle Ages. 


\section{Resumen}

La mayoría de los retablos-tabernáculo conservados por toda Europa presentan un carácter fragmentario o están repintados y reutilizados, lo que impide un análisis profundo de su programa iconográfico. Un estudio detallado de los ejemplares más antiguos conservados en su integridad procedentes del Bajo y Medio Rin, así como de algún ejemplo tardomedieval de esta región, arrojará algo de luz sobre asuntos tales como la construcción y evolución de sus formas, así como la iconografía y las técnicas empleadas en su creación y su posible impacto en el espectador. Este estudio se centra en un pequeño grupo de retablos-tabernáculo preservados casi por completo, lo que permite una observación detallada de todos los aspectos de su diseño. Esto posibilita un examen del conjunto de la escultura y de la pintura, de las estrategias desplegadas para resaltar la imagen de culto en su interior, así como de los puntos de conexión entre las imágenes en el interior y en el exterior. Otro aspecto de este estudio apunta a cuestiones relativas a los diferentes modos en que un altar puede adaptarse y mostrarse en un espacio (con los paneles laterales completamente abiertos o parcialmente cerrados) y a la percepción de estos artefactos, la mayoría de los cuales están diseñados para ser vistos desde todos sus lados — aspectos que hasta ahora han recibido escasa atención en los estudios sobre retablos-tabernáculos-. Los resultados de este breve estudio servirán también como trabajo preliminar para responder cuestiones acerca de la larga persistencia de los retablos-tabernáculo junto a nuevos tipos como los retablos con alas.

\section{Palabras clave}

Retablo-tabernáculo, altar, Renania, Alemania, escultura, pintura, Baja Edad Media.

A comparatively large number of tabernacle altarpieces have been preserved in their entirety from the region of the Lower and Middle Rhine with the earliest preserved example dating from $c$. 1360 and a series of examples created after I40O. This study presents them in three sections. The first two parts concentrate primarily on the oldest preserved examples: the so-called Kleiner Dom (c. 1360), the Chapelle Cardon (c. I400), and the 'small' Friedberg altarpiece (1325/1350 and I420). In the first section, the analysis concentrates on the dialectic between the two-dimensional surface of the painting and the spatial plasticity of the sculpture, which characterizes this altarpiece type in particular. Special attention will be given to a conspicuous occurrence: the double 'presence' of the central group 
of veneration in the interior as a sculpture and on the exterior as a painting, which is a frequently occurring cross-regional phenomenon. By including further examples with this peculiarity, the question is raised whether this strategy of emphasizing the venerated image can be associated with the altarpiece genre. The second section concentrates on the examples which hold statues of the Virgin Mary and the Christ child, and analyzes further strategies of harmonious connection between the painting and sculpture, which are manifest mostly in the interior of the altarpieces. The third, closing, section will travel further into the $15^{\text {th }}$ century and examine the potential for adjusting the tabernacle wings in different ways for communicating different messages. The tendency to configure the side views of the shrines with figurative images in the Later Middle Ages is a question that has received little attention so far, and speaks for an attentive study and awareness of the tabernacle shrine as a three-dimensional structure.

\section{THE KLEINER DOM AND THE DUPLICATED IMAGE}

The so-called Kleiner Dom (translated literally: small cathedral), now in the collection of the Bayerisches Nationalmuseum in Munich, is among the bestknown examples of carved altarpieces produced in Cologne in the $14{ }^{\text {th }}$ century and is at the same time an early representative of the type of altarpiece examined in this survey (Figs I-2). In many respects, the Kleiner Dom displays specific features of construction, design, and iconography. It originated from the Franciscan convent of St Clare in Cologne, abrogated in I802. This wealthy convent was the center of an intense relic cult, from which only a small number of items have survived (Hilger/Goldberg/Ringer, 1985, p. 43). ${ }^{2}$ Unlike most tabernacle altarpieces, which hold a sculpture of the Virgin and Child or another saint, in the center of this example a kneeling Mary and Gabriel depict the Annunciation. ${ }^{3}$ A half-length sculpture of God the Father and two angels float above them

' In recent years, the space behind the altar and the design of the shrines' back sides have received increasing attention. On this topic see Wittekind, 20I6, pp. 23-37, and Sander, ed., 2016.

${ }^{2}$ The Altar of the Poor Clares (c. I340), kept now in Cologne Cathedral as well as a sculpture of Mary (c. 1340) from the collection of the Museum Schnütgen (Inv. A 773) are items originating from the Franciscan convent alongside with the Kleiner Dom.

${ }^{3}$ Plurifigural scenes in tabernacle altarpieces are rare. Another example is the tabernacle altarpiece of St. Johann in Kronberg in Hessen (c. I420/30), showing in the center a plurifigural scene of the Death of the Virgin. An art technological peculiarity is the manufacture of the central group of veneration in clay. Further on this object see Droste, 20I8, pp. Io, note 24, 27 and 366, Droste, 
in reduced scale. When swung open, the panels reveal scenes from the childhood of Christ - the Adoration of the Magi, the Nativity, the Flight into Egypt, the Presentation of Christ at the Temple - separated from the central scene by depictions of St Peter and St Paul on the left side and St Agnes and St Gertrude of Nivelles on the right (Hilger/Goldberg/Ringer, 1990, p. 26). A peculiar compositional detail is the arrangement of the saints' figures. While Peter and Paul are aligned with the central scene of the Annunciation, the female saints devote their attention to the depictions on the side wings. Considering that the provenance of the canopy altar is a Franciscan monastery, the figure of the holy abbess is of particular importance. She witnesses the scene of Nativity, the iconography of which is somewhat unusual: Mary and Joseph kneel before the crib of the holy child, their hands raised in prayer to the newborn. The shape of the crib itself resembles an altar, emphasizing the sacral character of the scene and at the same time evoking reminiscence of the sacrifice of Christ and his presence in the Eucharist (Hilger/Goldberg/Ringer, 1990, p. 38). The side wings of the altarpiece are presented fully open due to their exhibition in a museum. If one imagines the side wings of the altarpiece inclined slightly inwards then meaningful connections between the individual scenes would merge into a harmonious unit. ${ }^{4}$ The apostles Peter and Paul as propagators of the teachings of Christ witness the Incarnation directly. Mary is kneeling with her back to Gabriel, her gaze directed to the scene of the Nativity and the abbess, underlining her role as a mediator for the spiritual community of the convent. A number of paintings from the $15^{\text {th }}$ century depicting altar ensembles containing baldachin altarpieces

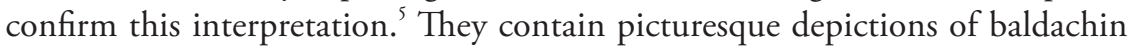
altarpieces with angled side wings that thus outline the architectonic character of the canopy and allow the sculpture to appear to be exhibited in an architectonic niche.

The interior of the tabernacle altarpiece is abundantly adorned with gold leaf and the background of the canopy area is additionally embellished with punched floral motifs. When closed, the panels show a painted depiction of the Annunciation, repeating the topic of the sculpted scene in the center. The name Kleiner

2019, pp. I82-188, and Dänekamp, 2019, p. 196). For an image of the artifact see Fig. I5 Kemperdick, in this volume.

${ }^{4}$ The question of the different modes of presentation of the wings is examined in the concluding section.

5 Two well-known examples of paintings which depict tabernacle altarpieces are works of Rogier van der Weyden (and workshop): The Exhumation of Saint Hubert (c. I430), National Gallery in London, and the Seven Sacraments altarpiece (c. I440), Royal Museum of Fine Arts in Antwerp. 
Dom emerged in the $19^{\text {th }}$ century and is related to the architectural roof superstructure, which has two spires and is adorned with gothic tracery resembling the towers of the Cologne Cathedral, that were only finished in the $19^{\text {th }}$ century but whose design was known from architectural plans as early as the $14^{\text {th }}$ century. The distinctive shape and suspiciously perfect execution of the altarpiece woodcarving led to a temporary conclusion that the whole roof superstructure was designed in neogothic style, which was proven wrong by a technological survey of the layers of paint (Ringer, 200I, p. 209). The two spires can be dismantled. Some traces of parchment in the interior of the tracery base prove the former existence of a closed compartment, probably serving for the preservation of relics (nowadays lost), which thus remained invisible (Hilger/Goldberg/Ringer, 1985, p. 50). The vertically accentuated shape of the crest and its architectural ornamentation including flying buttresses, finials, and tracery windows resembles the architectural ornamentation of contemporary large carved altarpieces such as the one in Oberwesel or the Altar of the Poor Clares, now in the Cologne Cathedral (Wolf, 2002, pp. 84-95 and 95-II2). The latter also originating from the Franciscan convent in Cologne, shares a number of technological and stylistical analogies with the Kleiner Dom. Both altarpieces are made of oak wood felled close to the same date. The punched-leaf ornament on the shrine's interior wall is identical to the decoration on the backgrounds on the exterior of the second pair of folding wings of the Altar of the Poor Clares. There is also a resemblance in the technique of joining the separate carved segments (Ringer, 200I, p. 213). Despite the similarities in the art technology and style, a decisive difference lies in how the relics are presented. While these were displayed visibly in the base zone of the Altar of the Poor Clares, they were concealed inside the Kleiner Dom. Consequently, the iconographic program comes to the fore, leaving less room for relics, a development that can be observed in late medieval winged altarpieces (Ringer, 200I, p. 2II). The Kleiner Dom is similar to some goldsmith work from the region, such as the reliquary of Charlemagne or the reliquary with three spires, both from the Aachen cathedral treasury (Ringer, 200I, p. 210). ${ }^{7}$ An art-technological survey of the object showed that not only do the appearance of the matte and gloss gilded surfaces (resembling hammered or cast gilded parts) support this relationship,

\footnotetext{
${ }^{6}$ The so-called 'Plan F' dates from $c$. 1320 and depicts the west front of the cathedral on a scale of I:42. Nowadays exhibited in the chapel of John in the cathedral. (Friese, 20I3, p. I49).

${ }^{7}$ For the Aachen Cathedral treasury see also Grimme, 1972. On the topic of micro-architecture as an instrument in the dissemination of style and form and also as a carrier of the ideological dimension of gothic architecture as symbol of Heavenly Jerusalem see Bucher, 1976, and Belghaus, 2008.
} 
but also the manufacture and attachment of the individual elements, especially those of the tracery architecture (Hilger/Goldberg/Ringer, 1985, pp. 49-50).

The exact function of the altarpiece remains unclear. Due to its small dimensions it may have been intended for a side chapel in a church interior. The altarpiece is designed to be viewed from a slightly upward perspective. Only through an elevated staging of the object or through kneeling can the spectator have a view of all the details of the interior. Additionally, from this point of view the architectural superstructure gains plasticity. ${ }^{8}$

The twofold representation of the Annunciation in the interior and on the exterior is unusual and has so far been addressed in only a few studies. 9 Although both scenes share the same iconography, there are a number of differences between them. The protagonists' robes on the outside are depicted in saturated colors, Gabriel's wings display a splendid interplay of colors. The background, in comparison, is simple: gold stars on a green background. Upon opening the altarpiece, the pictorial representation becomes more detailed and more splendid. The differentiated use of color recedes before an all-encompassing use of gold leaf, which covers the garments of the protagonists and the punched background. At the same time, the scene enters a new, third, dimension and thus reflects the theme of the Annunciation on a media level through a metaphorical act of Incarnation (Krischel, 2008, p. I05). The three-dimensional depiction is vivid, but appears more ethereal owing to the gilding. Although a hierarchy between the two depictions is clearly established and the higher position of the interior is undisputed, the masterful execution of the painted Annunciation on the exterior also shows great diligence and quality.

The remarkable duplication of the image program is not a single phenomenon, but a frequently occurring cross-regional iconographic peculiarity that reaches into the Later Middle Ages, lacking a systematic analysis so far. The outer side of the panels of the so-called Bosserode altarpiece (c. I470-I480), now in the evangelical parish church of Bosserode (Wildeck) display a fairly exact effigy of the pietà inside, only in more restrained colors (Figs 3-4). The altarpiece is not intact; at some unknown time, the wings were dismantled and placed together

${ }^{8}$ A similar point of view is presented in the Nativity scene on the interior of the wings: The Christ Child lies in an elevated position on the 'crib-altar' and looks downwards at Mary and Joseph as they kneel before him.

${ }^{9}$ Roland Krischel has devoted particular attention to this question, see Krischel, 2008, pp. IO2-IO9, and Krischel, 20I4, pp. 83-86. 
with the sculpture above the triumphal arch of the church..$^{\text {Io }}$ Since the painted depiction of the pietà came in direct contact with the humid wall, it has suffered the greatest loss of substance. As part of an extensive restoration, a simple wooden shrine was created and the painting was restored. Even with the panels severely damaged, the parallels between the depictions on the inside and on the outside are apparent. These are expressed above all in the posture of Christ and in the careful reproduction of the folds of Mary's veil. Similar to the Kleiner Dom, the visual impact increases when the altarpiece is open and enters the third dimension. Along with numerous similarities, both depictions display a number of evocative differences: for example, Mary's dark vestment on the exterior transforms into a vestment of golden tones when the altarpiece opens, and the wound in Christ's side gains plasticity. Painted depictions of the pietà are absolutely exceptional, which is why the image on the Bosserode altarpiece is a rarity and should be interpreted in light of this tabernacle altarpiece type.

Another example from the Later Middle Ages, the Holy Kinship altarpiece produced in Lübeck and now in St. Annen-Museum in that city, is an additional example that features a duplicate image (Figs 5-6) (Albrecht, ed., 2005, pp. 234-237). The shrine houses a sculpture of St Anne holding the holy child, who is handing an apple to the Virgin, standing to St Anne's right. When opened, the panels flanking the sculpture reveal images of the Holy Kinship. ${ }^{\text {II }}$ When closed, they depict, in the already described manner of duplication, the Virgin and Child with St Anne - Mary and the holy child have interchanged positions. This time Mary hands the Christ Child a flower, a gesture that appears many times in the scenes on the inside of the panels. ${ }^{\text {I2 }}$

An explanation for this re-occurring déjà-vu effect in the context of tabernacle altarpieces may be found in the desire for a permanent visual presence of the venerated image, even outside the high holidays and local church feasts (Kemp, ed., 1989, p. 33). The literal repetition of images has been addressed only marginally by researchers. In his profound study, Wolfgang Kemp referred to its function as a 'painted substitute' of the venerated image within the ensemble

${ }^{\text {Io }}$ For an image of this presentation, see: https://www.bildindex.de/document/obj20243348?me dium $=$ fmi50I4Io\&part=5 (retrieved September 20I9). Dänekamp, 2019, p. 196.

II The upper left side shows Salomas and Joseph, the top right Joachim and Cleophas, the lower left side shows Zebedeus and Mary Salome with her children, James the Greater and John the Evangelist, the lower right side shows Alphaeus and Mary of Cleopas with her children: James the Less, Simon, Jude and Josephus Justus.

${ }^{12}$ The flowers are the red carnation (lat. carnatio), a symbol of the incarnation (Kuhn, 20I8, p. 45, p. I42), and probably a white anemone, attributed to Mary. 
(Kemp, ed., 1989, p. 33). The act of opening creates a special effect in which the plain two-dimensional painted surface of the image is literally 'burst open', letting it emerge in a three-dimensional shape. Its tangible plasticity and more abundant decoration, visible frontally and laterally, move closer to the reality of the spectator.

This raises the question of who witnessed the immediate transformation of the painting into a three-dimensional sculpture. If the altarpieces were designed for the church interior, in most cases it was the task of the sacristan to prepare them for the liturgy and, depending on the significance of the church feast, to additionally decorate them with candles and textiles. The opening and closing of the winged altarpieces was also amongst his tasks in the daily routine. A sacristan book dating from I493, originating from the St. Lorenz parish church in Nuremberg, provides a vivid idea of the various alterations of the altarpieces (Gümbel, 1928). Precise instructions are given as to which state of transformation of the numerous altars of the church were prepared in advance and on which holidays. ${ }^{\mathrm{I3}}$ It can therefore be assumed that the priest and the religious community were confronted with an actual state - that is, either open or closed - of the altarpiece. A direct witnessing of the opening and closing of the altarpiece related to its ven-

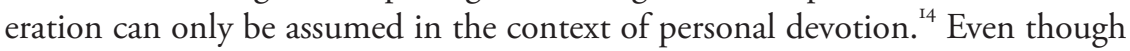
the majority of viewers, primarily the religious community, were not present as the altar was opened and closed, they were certainly aware of the repetition of the image program, being much more familiar with the appearance of the closed shrine. Heike Schlie and Valerie Möhle examined the relationship between the mechanisms of veiling and unveiling using the example of the winged altarpiece and the complex associative relations among the differing layers of images (Schlie, 2004, pp. 23-43; Möhle, 2006, pp. 54-73). In this context, Möhle states that exact repetitions are rather exceptional in the case of winged altarpieces (Möhle 2006, p. 59). Analogies, parallels, and one view as a secondary version

${ }^{13}$ Similar instructions are found in the sacristan book of the parish church St. Sebald in Nuremberg dating from 1482 (Gümbel, 1929).

${ }^{14}$ In his analysis of the twofold depiction of the Annunciation on the interior and on the exterior of the Kleiner Dom, Roland Krischel assumes that the altarpiece was designated for personal devotion and pays special attention to the changed posture of the figures: when the altarpiece is open the standing Mary and Gabriel appear kneeling. Krischel interprets this occurence as an instruction for the observer (a Franciscan nun) who is at the same time the operator of the opening and closing of the altarpiece to move in unison with the characters depicted (Krischel, 20I4, p. 83), although a lack of information about the primary context and use of the object make it impossible to confirm this assumption. 
of the other are much more common. This feature is one of the main differences of the winged altarpieces from the tabernacle altarpieces: repetitions are per se extrinsic to its system. Following the reflections of Schlie and Möhle, Dänekamp emphasizes the role of the viewer's memory in perceiving not only the similarities but mainly the differences between the duplicated images (Dänekamp, 2019, p. 199). Thus, she recognizes the potential of the object to intensify the contemplative immersion of the spectator. The more splendid appearance of an altarpiece's interior added to the interchanging of the figure's position or recurring motifs are seen precisely through comparative vision. Finally, it should be considered whether the repetition is a phenomenon that came to be associated increasingly with the genus of the tabernacle altarpiece over time.

\section{THE 'SMALL' FRIEDBERG ALTARPIECE AND THE STAGING OF THE VIRGIN AND CHILD}

Another prominent example from the Rhine region are the so-called Chapelle Cardon and the 'small' Friedberg altarpiece, which house the enthroned Virgin and Child. The Chapelle Cardon (Fig. I6 Kroesen/Tångeberg, in this volume) dates from around $\mathrm{I} 400$ and is named after the artist and collector Charles-León Cardon (I850-1920). ${ }^{15}$ Similar to the Kleiner Dom, this tabernacle altarpiece has a superstructure in the shape of a tower, which, however, is a later addition that may have been made by Cardon himself. It remains an open question whether a damaged former structure was integrated into a new one or whether a completely new design was created. Nevertheless, due to its proportions, the square base preserved from the original architectonic model suggests that the original tower had more slender proportions than those of the present form. The painting is the oeuvre of an artist who worked on the Lower Rhine, possibly in the region of Geldern or in the Duchy of Kleve, where the influence of Cologne and Flemish masters was noticeable. ${ }^{16}$ Cologne's influence can also be seen in the statue of the Virgin. Due to its small size, it is assumed that the altarpiece was designed as a

I5 0.99 x 0.59 cm, Louvre Paris, Inv. R.F. 1343. For the Chapelle Cardon see: Vor Stefan Lochner..., 1974, cat. 46, pp. I08-109; Foucart-Walter/Guillot de Suduiraut, 1990, pp. 73-75; Guillot de Suduiraut, 1992, pp. 65-68.

${ }_{16}$ Another tabernacle altarpiece with similar dimensions in the collection of the Museum Mayer van den Bergh in Antwerp (Inv. 359) shows stylistically comparable depictions on the interior wings, so that a provenance from the Meuse/Lower Rhine region can be assumed. The sculpture of the altarpiece ensemble is missing (Vor Stefan Lochner..., I974, p. I09, cat. 48). 
mobile object, to serve for personal devotion. ${ }^{17}$ On the inside of the panels scenes from the life of Mary are depicted, each scene extending over the area of both the inner and outer wings: the Annunciation and Visitation, the Nativity, and the Adoration of the Magi on the left side; and on the right the Flight into Egypt, the Presentation of Jesus at the Temple, the Massacre of the Innocents. The scene in the uppermost register of the outer right wing is difficult to interpret; currently only a solitary altar is depicted, perhaps originally the Fall of the Idols or the Circumcision. Most of the scenes extend over both segments of the wings, joining them like hinges and inviting an angled presentation of the wings in order to emphasize the connection between the protagonists. The symbiotic relationship between painting and sculpture is manifested in this example by integrating the sculpture into the plain level of painting. The Magi to the left side venerate the Virgin Mary directly; the sculpture is related to the back panel of the canopy by the punched halo and thus oscillates between the levels of painted and three-dimensional reality. When closed, the exterior of the wings picks up the compositional layout of the inner ones, although the images are lost today.

The iconographic tradition of the Chapelle Cardon is reflected in the so-called 'small' Friedberg altarpiece from the Middle Rhine region (Figs 7-8). The shrine, dating from around $\mathrm{I} 42 \mathrm{O}$, is approximately a hundred years younger than the statue of the virgin. The question of whether sculpture and shrine originally belonged together is much-discussed in the research as described below. The ensemble was not documented until I806 (Kappeler-Meyer, 2015, p. 4). Although there are no sources that would provide explicit information about the fabrication of the sculpture of the Virgin, the coherence of the figures seems natural. The differing dimensions of the two segments raised doubts at first; some authors explained them by the fact that the ensemble was created to be viewed from a

${ }^{17}$ An interesting question to verify is whether the small compartments with tracery lattices in the base zone were used for the safekeeping and presentation of relics, analogous to the compartments in the previous example from Cologne.

${ }^{18}$ A neglected aspect of tabernacle altarpieces is their appearance on the exterior. Only a small number of early tabernacle altarpieces are extant with objective painting on the exterior. Mostly they show non-figural decoration For an examination of the exterior of early tabernacle altarpieces (II5O-I350) see the pioneering study of Elisabeth Andersen (Andersen, 20I5) and her study in the present publication. Andersen presents an altarpiece from Castile and León (c. I275-I300, Metropolitan Museum of Art, The Cloisters Collection, New York, Inv. 55.62 a, b, and 1977.94) which displays scenes from the Passion of Christ on its exterior. A similar iconography can be assumed for the missing depictions of the Chapelle Cardon, correlating with the mariological connotation of the interior design. Another possible interpretation is that a depiction of standing saints adorned the exterior. 
strongly upward perspective (Woelk, ed., 1995, p. 29, and Gast 1998, p. 58); from this point of view the differences would vanish. Since the exhibition Beschaffenheit des Himmels (24 April to 22 July 2018) at the Hessisches Landesmuseum in Darmstadt, there can no longer be doubts about the conceptual unity of shrine and sculpture. The museum team recognized and restored the foundation of the altar shrine and the pedestal for the sculpture (see Fig. 7). ${ }^{19}$ By thus raising the sculpture, it returned to its original position in the tabernacle shrine, with the head of the Virgin Mary matching the shape of the halo. The contours of the figure also correspond in the main to the recessed surface in the color of the shrine's back wall. Matters are quite different with the provenance of the ensemble from the parish church of Friedberg - a question which remains open. Friedrich Back related a venerated sculpture of Mary in the chapel of the Friedberg castle, described in the castle's chronicle, to the sculpture of the Virgin (Back, 1932, p. 213 , note 17$){ }^{20}$ In this scenario the statue would have been exhibited without a tabernacle altarpiece in the chapel of the Friedberg castle. In 1383 , the new choir of the castle's church, the main altar, other altars as well as a statue of Mary and Georg were inaugurated (Dieffenbach, 1857, p. 64) and relics were added to the sculpture of Mary, installed behind a round glass compartment in the chest (Gast, I998, p. 58). Thomas Foerster assumes that this led to an increased flow of pilgrims, which resulted in the translation of the venerated sculpture to the city parish church and in 'equipping' it with a tabernacle shrine as a measure of better protection and richer presentation (Foerster, 20I8, p. 252). Although his assumption is plausible, there is a lack of sources which would confirm an immediate connection between the translation of the sculpture and the creation of the tabernacle shrine. Irrespective of the exact date, however, enclosing the sculpture in the tabernacle shrine is an approach that makes explicit the suitability of such altarpieces for the preservation and veneration of a single sculpture. Traditionally, scenes from the life of Mary adorn the inner surface of the panels. Several representations of Christ's childhood appear on the inside of the shrine wings; they depict the Annunciation, the Visitation, Christ in the Temple, the Nativity and the Flight into Egypt in reverse order. Like other cases, most of the depictions stretch over both wing segments and gain plasticity if the outer wings are slightly

I9 I would like to thank Dr. Thomas Foerster for this explanation.

${ }^{20}$ The so-called castle's chronik of Krafto von Rockenberg is only preserved in a transcription from Johann Philipp Dieffenbach dating from 1851. The transcription is nowadays kept in the university and regional library in Darmstadt (Hs. 3337). The Virgin is addressed as: ymago beate Marie virginis, quoted in Gast, 1998, p. 58. 
closed (see Fig. 7). The scene of the Annunciation is well executed and appears on both the outer and inner surfaces of the wings. A notable detail on the exterior image is the canopy structure which adorns the throne of the virgin and at the same time resembles the three-dimensional architectonic structure of the interior. Further iconographic motifs connect the canopy shrine with the sculpture of Mary. A special art technological feature of the altar shrine is the high quality execution of the background. ${ }^{21}$ In a dense tendril mesh at the sides of the nimbus, birds are depicted that appear to be eagles holding pigeons. Below them, angels and hares grasping lions can be seen (Foerster 2018, p. 253). The microcosm of floral and animal motifs complements the depiction of the holy child, who is presented holding a bird in his hand (incompletely preserved).

The dialectic of plain surface and plasticity became more cultivated during the Early Modern age. A tabernacle altarpiece from $c$. I5IO-I520 from the Lower Rhein or Flanders in the Loyola University Museum of Art in Chicago depicts the Crucifixion of Christ as an illusionistic combination of plastic figures with deep spatial scenery painting (Krischel, 2008, p. I03). In contrast to the objects examined so far, painting and sculpture are not two related counterpoints but parts of the same layer of depiction, merging and forming different components of the same image.

\section{CONCLUDING NOTES: THE FOLDING OF SPACE}

This study was dedicated to the analysis of tabernacle altarpieces preserved in their entirety from the region of the Lower and Middle Rhine with the earliest preserved example dating from $c$. 1360 and a series of examples created after I400. Tabernacle altarpieces were customary for a long time in the region of Middle Rhine, as the altarpiece in the chapel of Darsberg, dating from around I460, shows (Figs 9-IO) (Hartwieg/Lüdke, 1994, p. 57; Droste, 2018, pp. IIO and $\left.{ }^{176-I 83}\right) .{ }^{22}$ When opened like the previous examples, the inside of this well pre-

${ }^{21}$ The back wall of the shrine is covered with zwischgold (a mixture of gold and silver) and decorated with complex brocade patterns. The animal motifs on the imitated fabric were repeated almost identically using templates. They were engraved in the primer layer before the zwischgold was applied; the spaces between them were additionally decorated with zigzag cuts. As a result, the patterns appear smooth and the background imitates the textile structure of fabric (Foerster, 20I8, p. 26I, note 65).

${ }^{22}$ Form and motif intersections can be seen on an altarpiece from the end of the $15^{\text {th }}$ century from Wachenheim an der Pfrimm. The altarpiece represents a hybrid form, a combination of a tabernacle 
served altarpiece does not show scenes from the life of Mary but standing saints against a golden background, ${ }^{23}$ with the Annunciation on the outside panels. Standing figures of saints can also be seen on the exterior face sides: Saints Valentin and Wendelin. Compared to earlier examples, the size is larger, probably also arising from the fact that large-scale tabernacle altarpieces from the thirteenth and fourteenth century are rarely preserved in their entity. A further peculiarity is the accent on all the sides of the outer shell, where the depiction emphasizes the three-dimensional structure of the shrine and invites the viewer to multiple points of view. Similarly, representations of SS Peter and Paul adorn the sides of the Bosserode altarpiece. In order to see all the images on the outside, the viewer would have to explore the space around the object. Only then can the viewer see the apostles witnessing the lamentation of Mary.

Furthermore, one should consider the multiple variations on the opening of the panels. They are normally perceived according to their museum presentation: fully opened and resembling the plain surface of a retable. Yet their construction allows for a broader range of possibilities. Less attention has been given to the variations of angled openings and the resulting new connections between scenes from the iconographic programs. For example, if we imagine the tabernacle altarpiece from Darsberg with the side wings angled in, we would be witnessing an interesting variation of a sacra conversazione: the saints would encircle the sculpture of Mary. For the Chapelle Cardon and for the Kleiner Dom it was already noted above that the context of the image program unfolds completely with the wings angled slightly closed.

At the conclusion of this brief study the question remains as to the reasons for the long durability of tabernacle altarpieces alongside newer forms such as winged altarpieces. The abundant number of preserved examples up until the end of the $15^{\text {th }}$ century, also beyond the Rhineland and particularly in Sweden, shows explicitly that this was still a popular altarpiece type. The elegant open construction of a canopy is perfectly suitable to establishing a border between the framed object and its surrounding environment, at the same time emphasizing its prominence and allowing its three dimensionality to stay visible and tangible. Therefore, the shell of a tabernacle served as a primary motif of cult presentation

and a winged altarpiece; its shrine features only one pair of wings. It was probably created for the former parish church of St. Remigius by a master from the nearest art center - Worms (Schedl, 2016, pp. 64-69). For an image see: https://www.bildindex.de/document/obj20327267?.part=3\&medium =fmi456I79 (retrieved September 2019).

${ }^{23}$ On the left side are St Nicolaus and St Catherine, on the right side St Barbara and St Sebastian. 
throughout the centuries (Fuchß, I999, p. I40). On the one side, the convenient format of tabernacle altarpieces made them perfect for exhibition in side chapels, as a segment of multipart altarpiece ensembles or for private meditation; on the other hand, their specific form allowed the presentation and concentration of devotion on one single venerated sculpture, whose value, as the examples have shown, was additionally occasionally underlined by the effect of duplication of the iconographic program. Modes of concealing or displaying objects were central among the strategies of medieval art. This enhanced and controlled the sacredness of these objects by preventing the permanent visual accessibility. Tabernacle altarpieces also embody the potential of transformation inherent in every winged altarpiece, yet some of them offering a different approach by applying the effect of duplication. Thus a modified image of the venerated sculpture implied its presence at all times in the closed tabernacle.

\section{BIBLIOGRAPHY}

Albrecht, U. (ed.), 2005: Corpus der mittelalterlichen Holzskulptur und Tafelmalerei in Schleswig-Holstein, vol. I: Hansestadt Lübeck, St. Annen-Museum, Lübeck.

Andersen, E., 2015: "Madonna Tabernacles in Scandinavia c. II5O-c. I350", Journal of the British Archaeological Association, I68/I, pp. 165-185.

Back, F., I932: Ein Jahrtausend künstlerischer Kultur am Mittelrhein, Darmstadt.

Belghaus, V., 2008: "Gründungslegende und Stiftersignatur: Zur Funktion des Architekturzitats am mittelalterlichen Reliquiar", in Ch. Kratzke \& U. Albrecht (eds), Mikroarchitektur im Mittelalter: Ein gattungsübergreifendes Phänomen zwischen Realität und Imagination, Leipzig, pp. 409-431.

Bucher, F., 1976: "Micro-Architecture as the 'Idea' of Gothic Theory and Style", Gesta, I5/I-2, pp. I-89.

Dänekamp, K., 2019: "Der Bosseroder Altar", in U. Schütte, H. Locher, K. Niehr, J. Sander \& X. Stolzenburg (eds), Mittelalterliche Retabel in Hessen, vol. 2: Werke, Kontexte, Ensembles, Petersberg, pp. 196-206.

Dieffenbach, P., I857: Geschichte der Stadt und Burg Friedberg in der Wetterau, Darmstadt.

Droste, H., 20I8: Spätgotische Schnitzretabel am Mittelrhein I450-I530, Ph.D. diss., Goethe-Universität.

—, 2019: "Der Kronberger Marientod-Altar", in U. Schütte, H. Locher, K. Niehr, J. Sander \& X. Stolzenburg (eds), Mittelalterliche Retabel in Hessen, vol. 2: Werke, Kontexte, Ensembles, Petersberg, pp. I82-188. 
Foerster, T., 20I8: "Erinnerungsrundgang durch die Sonderausstellung «Beschaffenheit des Himmels»", Kunst in Hessen und am Mittelrhein. Neue Folge, II (Gedenkschrift für Dr. Theo Jülich), pp. 233-26I.

Foucart-Walter, E. \& Guillot de Suduiraut, S., I990: "Chapelle Cardon", in Polyptyques - Le tableau multiple du Moyen-âge au vingtième siècle, exhibition catalogue, Paris, pp. 73-75.

Friese, H., 2013: Der Kölner Dom, Cologne.

Fuchß, V., I999: Das Altarensemble. Eine Analyse des Kompositcharakters früh-und hochmittelalterlicher Altarausstattung, Weimar.

Gast, U., 1998: Der große Friedberger Altar und der Stilwandel am Mittelrhein nach der Mitte des I4. Jahrhunderts (Neue Forschungen zur deutschen Kunst, I), Berlin.

Grimme, E. G., I972: Der Aachener Domschatz (Aachener Kunstblätter, t. 42), Düsseldorf.

Guillot de Suduiraut, S., 1992: "Chapelle Cardon", in Sculptures allemandes de la fin du Moyen-Age dans les collections publiques françaises, I400-I530, exhibition catalogue, Paris, pp. 65-68.

Gümbel, A., I928: Das Mesnerpflichtbuch von St. Lorenz in Nürnberg vom Jahre 1493 (Einzelarbeiten aus der Kirchengeschichte Bayerns, vol. 8), Nuremberg.

- - 1929: Das Mesnerpflichtbuch von St. Sebald in Nürnberg vom Jahre 1482 (Einzelarbeiten aus der Kirchengeschichte Bayerns, vol. II), Nuremberg.

Hartwieg, B. \& Lüdke, D., 1994: Vier gotische Tafeln aus dem Leben Johannes' des Täufers, Karlsruhe.

Hilger, H. P., Goldberg, G. \& Ringer, C., 1985: “'Der Kleine Dom'-zum kölnischen Schreinaltärchen des I4. Jahrhunderts im Bayerischen Nationalmuseum in München”, Zeitschrift des deutschen Vereins für Kunstwissenschaft, 39, pp. 40-69.

—, 1990: 'Der Kleine Dom' (Bayerisches Nationalmuseum Bildführer, I8), Munich.

Kappeler-Meyer, A., 2015: Darsberg (Neckarsteinach), Ev. Kirche - Baldachinretabel, um I450/I460 (Forschungsprojekt Mittelalterliche Retabel in Hessen, 20I5). URL: http://archiv.ub.uni-heidelberg.de/artdok/volltexte/20I7/4739 (retrieved September 2019).

Kemp, W. (ed.), 1989: Der spätgotische Altar von Bosserode, Marburg.

Krischel, R., 2008: "Mediensynthesen in der spätmittelalterlichen Sakralkunst. Das Altarbild als Kulisse für liturgische Gegenstände und Handlungen. Mit einem Beitrag von Tobias Nagel", Wallraf-Richartz-Jahrbuch, 69, pp. 73-169. 
__ 20I4: "Bilder, die klappen. Zur Kinetik religiöser Gemälde im spätmittelalterlichen Köln”, Wallraf-Richartz-Jahrbuch, 75, pp. 5I-I30.

Kuhn, H., 2018: Die Heilige Sippe und die Mediengeschichte des Triptychons: Familie und Bildrhetorik in Quentin Massys' Annenaltar, Emsdetten and Berlin.

Möhle, V., 2006: "Déjà vu: Bildsysteme zum Klappen", in S. Bogen, W. Brassat \& D. Ganz (eds), Bilder, Räume, Betrachter: Festschrift für Wolfgang Kemp zum 60. Geburtstag, Berlin, pp. 54-73.

Ringer, C., 200I: "Der 'Kleine Dom' - ein kölnischer Schnitzaltar um 1360", in H. Krohm, K. Krüger \& M. Weniger (eds), Entstehung und Frühgeschichte des Flügelaltarschreins, Wiesbaden: Reichert, pp. 205-2I4.

Sander, J. (ed.), 2016: Schaufenster des Himmels. Der Altenberger Altar urnd seine Bildausstatung - Heaven on Display: The Altenberg Altar and Its Imagery, exhibition catalogue, Frankfurt.

Schedl, M., 20I6: Tafelmalerei der Spätgotik am südlichen Mittelrhein, Mainz.

Schlie, H., 2004: "Wandlung und Offenbarung. Zur Medialität von Klappretabeln”, Das Mittelalter. Perspektiven mediävistischer Forschung, 9/I (K. Kellermann [ed.], Medialität im Mittelalter), pp. 23-43

Vor Stefan Lochner..., 1974: Vor Stefan Lochner. Die Kölner Maler von I300 bis 1430, exhibition catalogue, Cologne.

Wittekind, S., 20I6: "Hinter dem Altar: Nutzungskonzepte vor und nach der Einführung von Altarretabeln”, in J. Sander, S. Seeberg \& F. Wolf (eds), Aus der Nähe betrachtet: Bilder am Hochaltar und ihre Funktionen im Mittelalter. Beiträge des Passavant-Kolloquiums, Städel Museum, Frankfurt am Main, I3.I4. November, 20I5, Berlin, pp. 23-37.

Woelk, M. (ed.), I995: Von Jenseits ins Diesseits. Sakrale Bilder des Spätmittelalters aus den Beständen des Hessischen Landesmuseums und aus Privatbesitz, exhibition catalogue, Darmstadt.

Wolf, N., 2002: Deutsche Schnitzretabel des 14. Jahrhunderts, Berlin. 


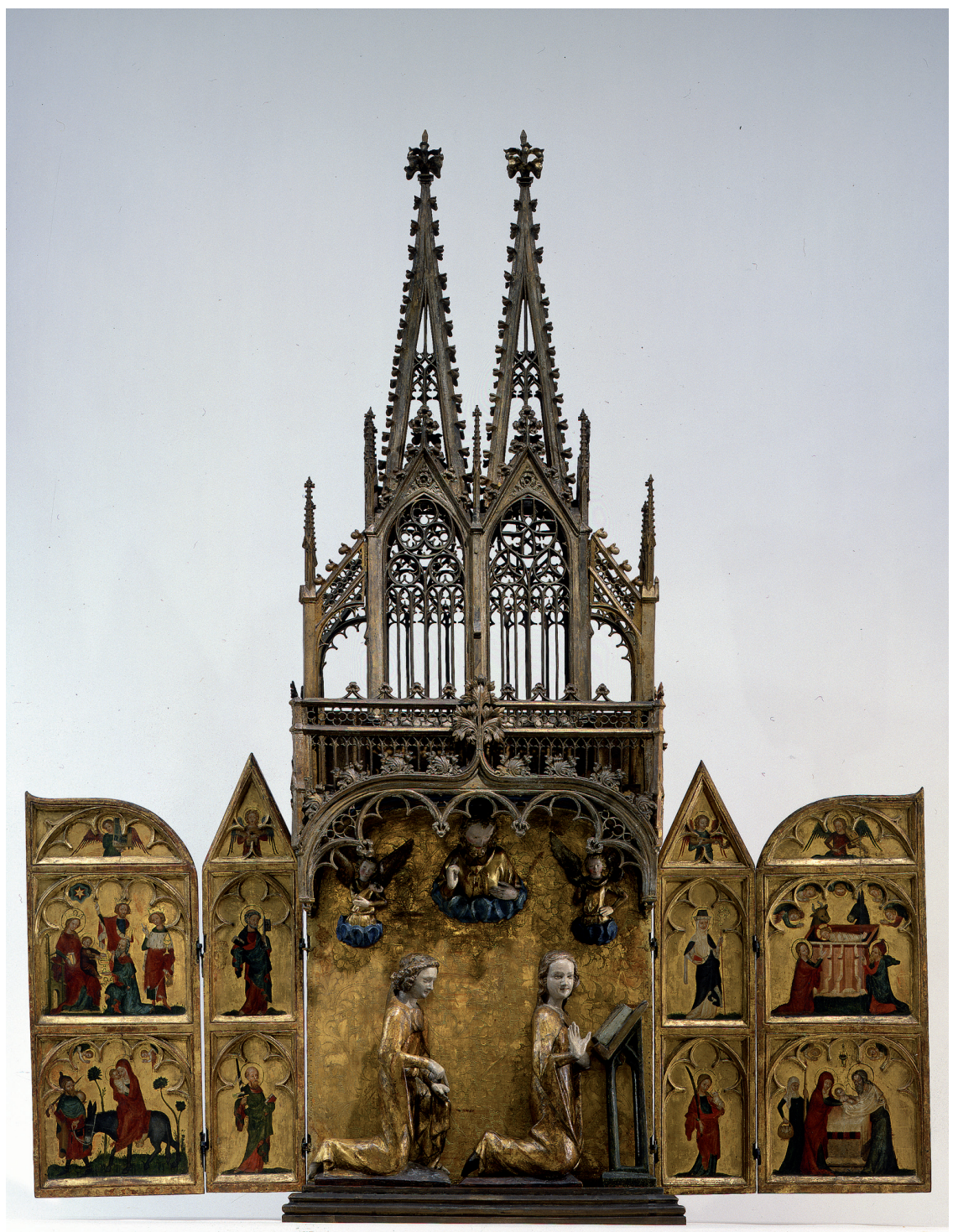

Fig. I. The so-called Kleiner Dom, Cologne, c. 1360 , I47.5 x $123.5 \mathrm{~cm}$, Bayerisches Nationalmuseum München, on loan from Wittelsbacher Ausgleichsfond, Inv. L-MA 1968 a-d, opened, (C) Bayerisches Nationalmuseum München, Fotos: Haberland, Walter. 


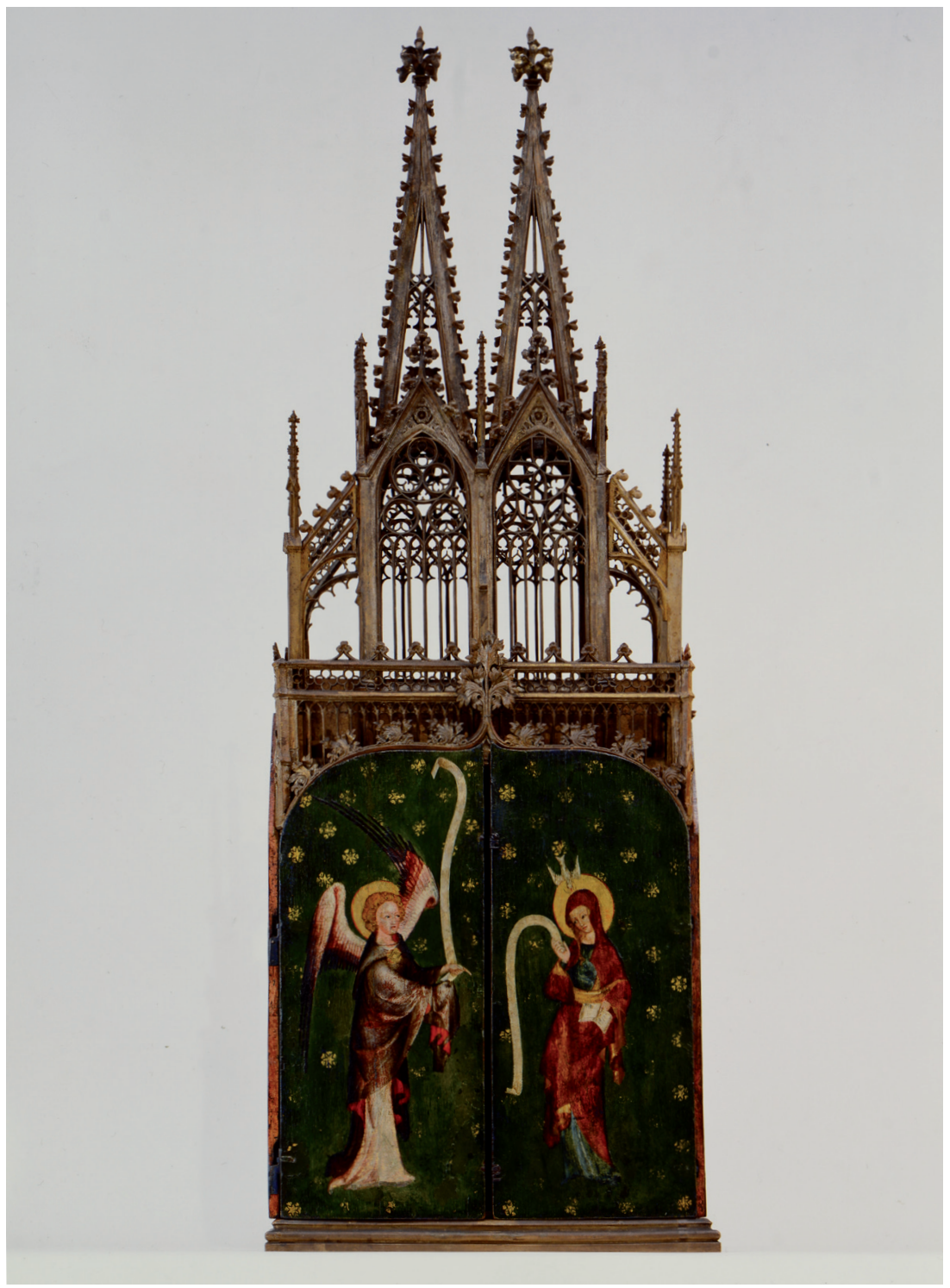

Fig. 2. The so-called Kleiner Dom, Cologne, $c .1360,147.5$ x $123.5 \mathrm{~cm}$, Bayerisches Nationalmuseum München, on loan from Wittelsbacher Ausgleichsfond, Inv. L-MA I968 a-d, closed, (C) Bayerisches Nationalmuseum München, Fotos: Haberland, Walter. 


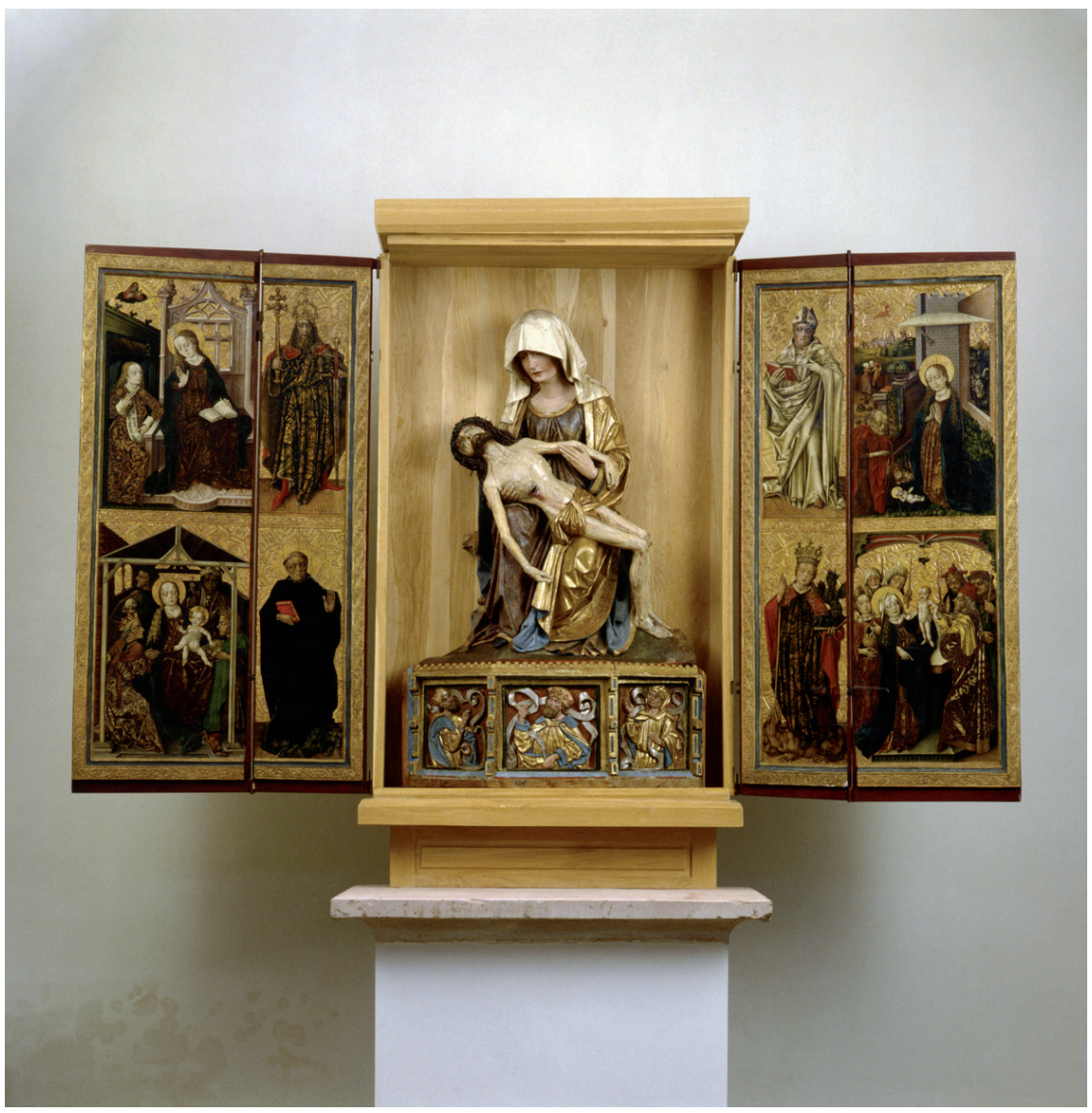

Fig. 3. Bosserode altarpiece, c. I470-I480, I2I.5 X IOI X $29 \mathrm{~cm}$ (sculpture), $178 \times 96 \mathrm{~cm}$ (left double wing), I78 x $92 \mathrm{~cm}$ (right double wing), parish church of Bosserode, Wildeck (Kreis Hersfeld-Rotenburg), opened, (C) Bildarchiv Foto Marburg/Dagmar Peil. 


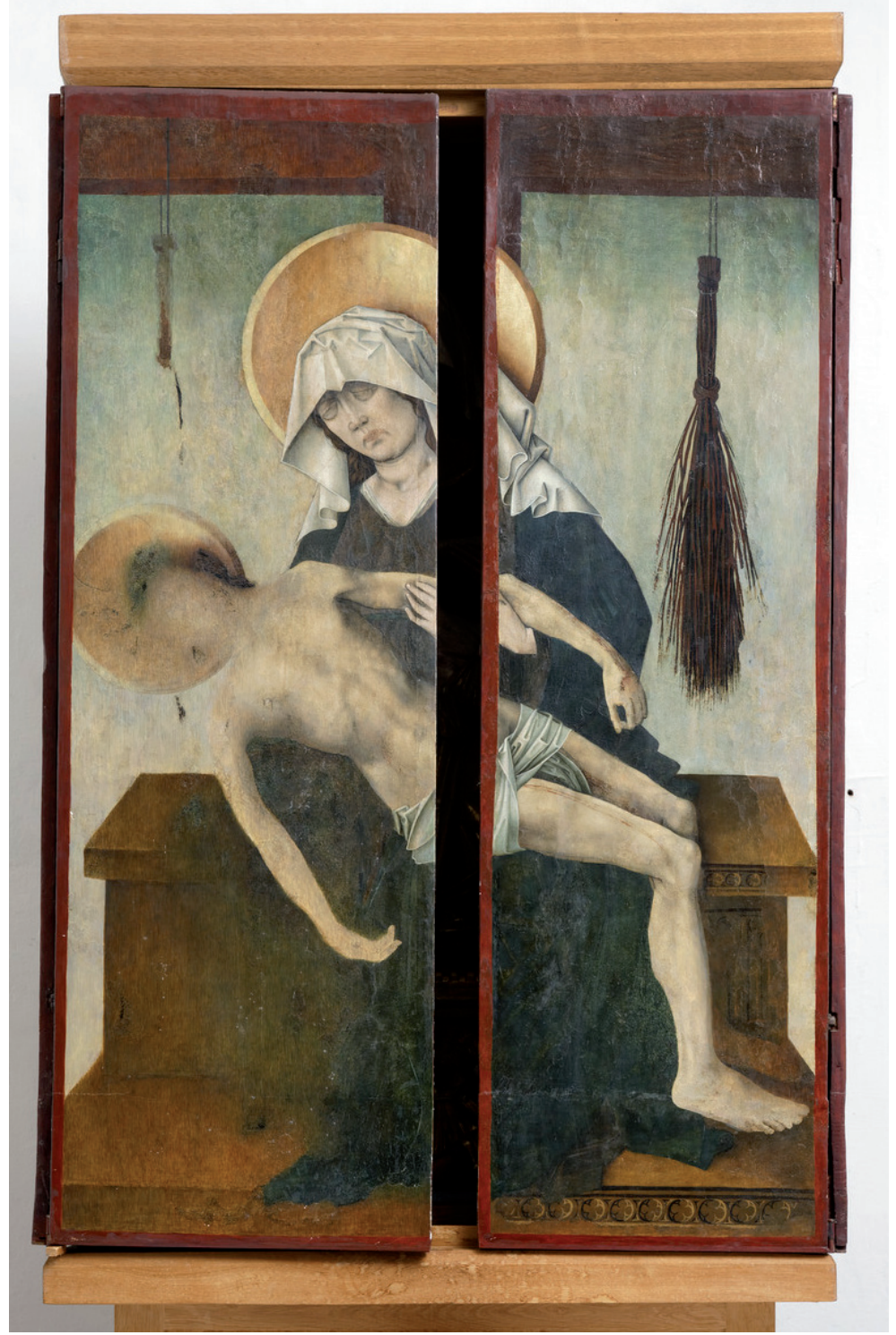

Fig. 4. Bosserode altarpiece, $c$. I470-I480, I2I.5 X IOI x $29 \mathrm{~cm}$ (sculpture), $178 \times 96 \mathrm{~cm}$ (left double wing), $178 \times 92 \mathrm{~cm}$ (right double wing), parish church of Bosserode, Wildeck (Kreis Hersfeld-Rotenburg), closed, (C) Bildarchiv Foto Marburg/Uwe Gaasch. 


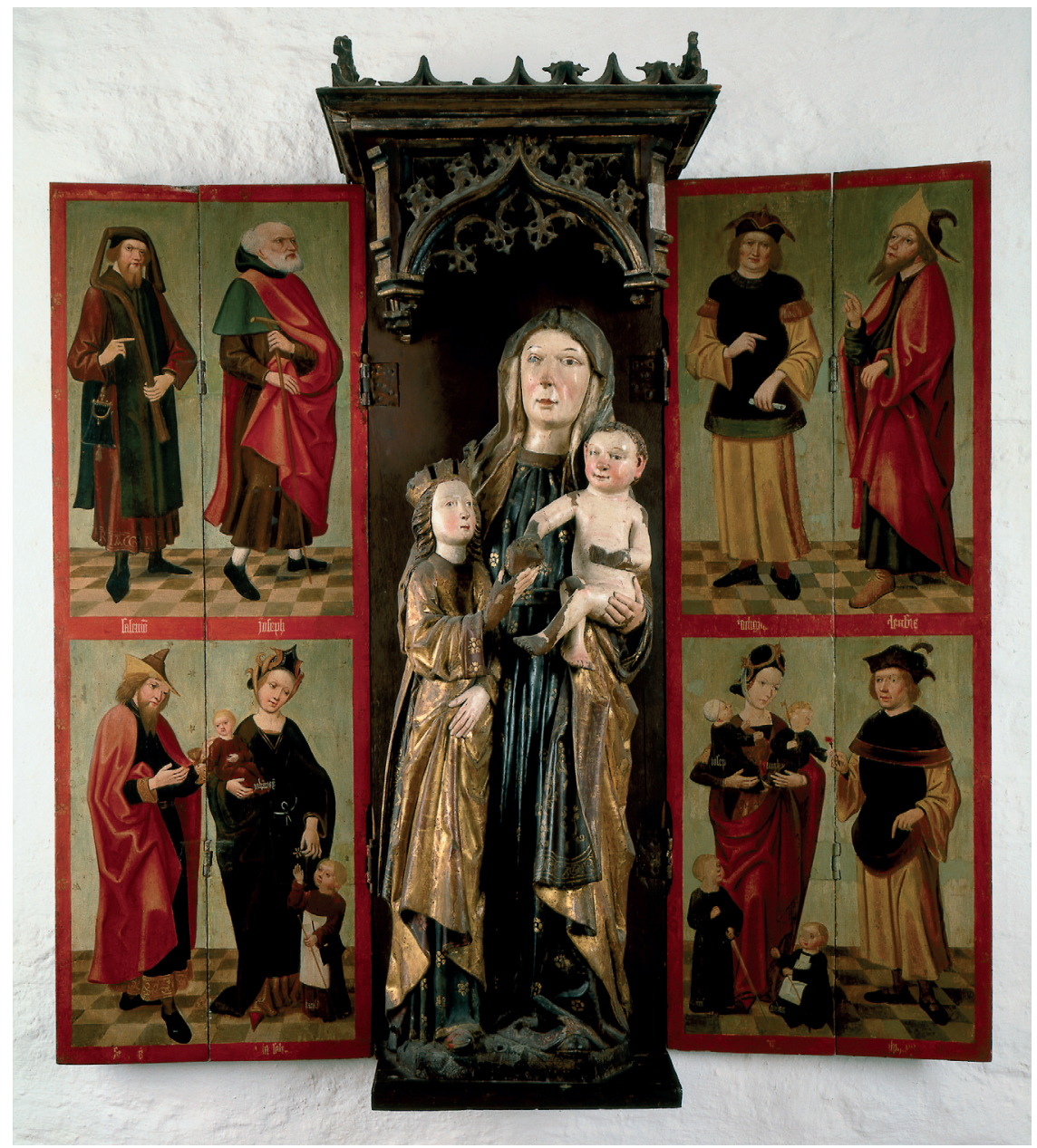

Fig. 5. Holy Kinship altarpiece, late $15^{\text {th }}$ century, I3I X 57.5 X $29 \mathrm{~cm}$ (shrine), II8 X $20 \mathrm{~cm}$ (wings), St. Annen-Museum Lübeck, Inv. 20, opened, (C) St. Annen-Museum Lübeck/Fotoarchiv. 


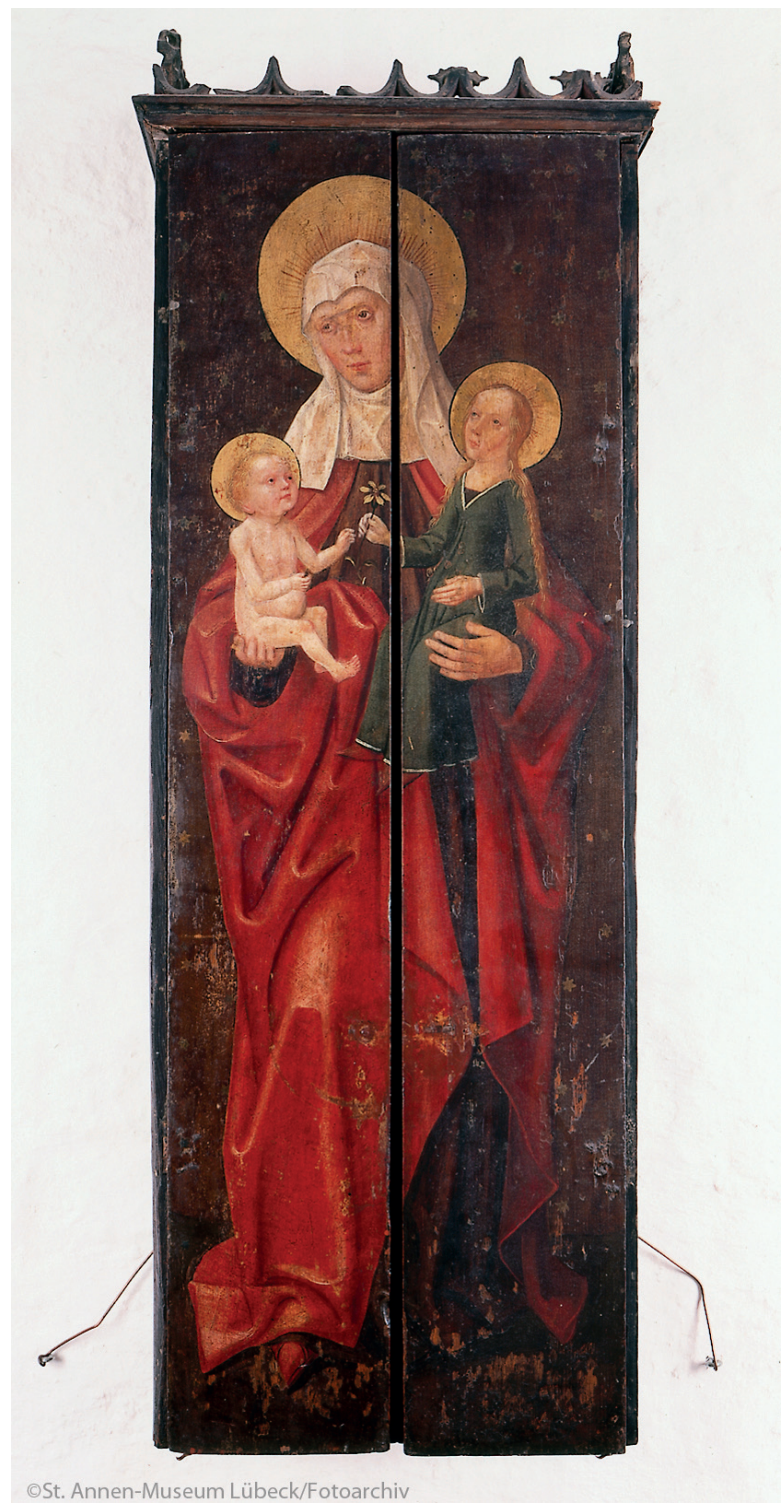

Fig. 6. Holy Kinship altarpiece, late $15^{\text {th }}$ century, I3I X $57.5 \times 29 \mathrm{~cm}$ (shrine), II $8 \times 20 \mathrm{~cm}$ (wings), St. Annen-Museum Lübeck, Inv. 20, closed, (C) St. Annen-Museum Lübeck/Fotoarchiv. 


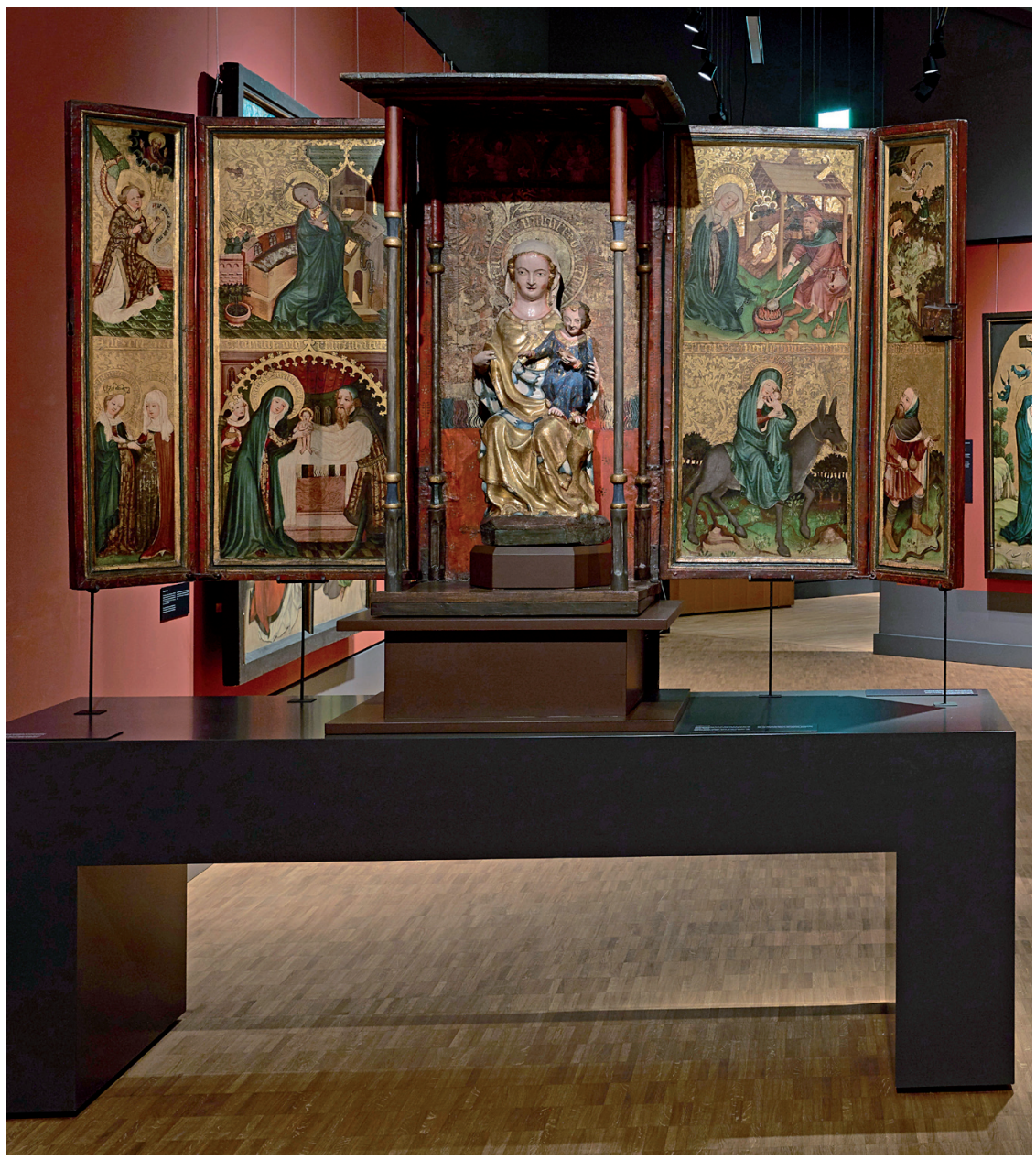

Fig. 7. The so-called 'small' Friedberg altarpiece,

Middle Rhine (probably Frankfurt), c. I325/50 (sculpture) and c. I420 (shrine), $78.5 \times 34.5 \times 25.5 \mathrm{~cm}$ (sculpture), $\mathrm{I} 20 \times 240 \mathrm{~cm}$ (shrine when opened),

Hessisches Landesmuseum Darmstadt, Inv. GK 2, opened,

(C) Hessisches Landesmuseum Darmstadt, Foto: Wolfgang Fuhrmannek. 


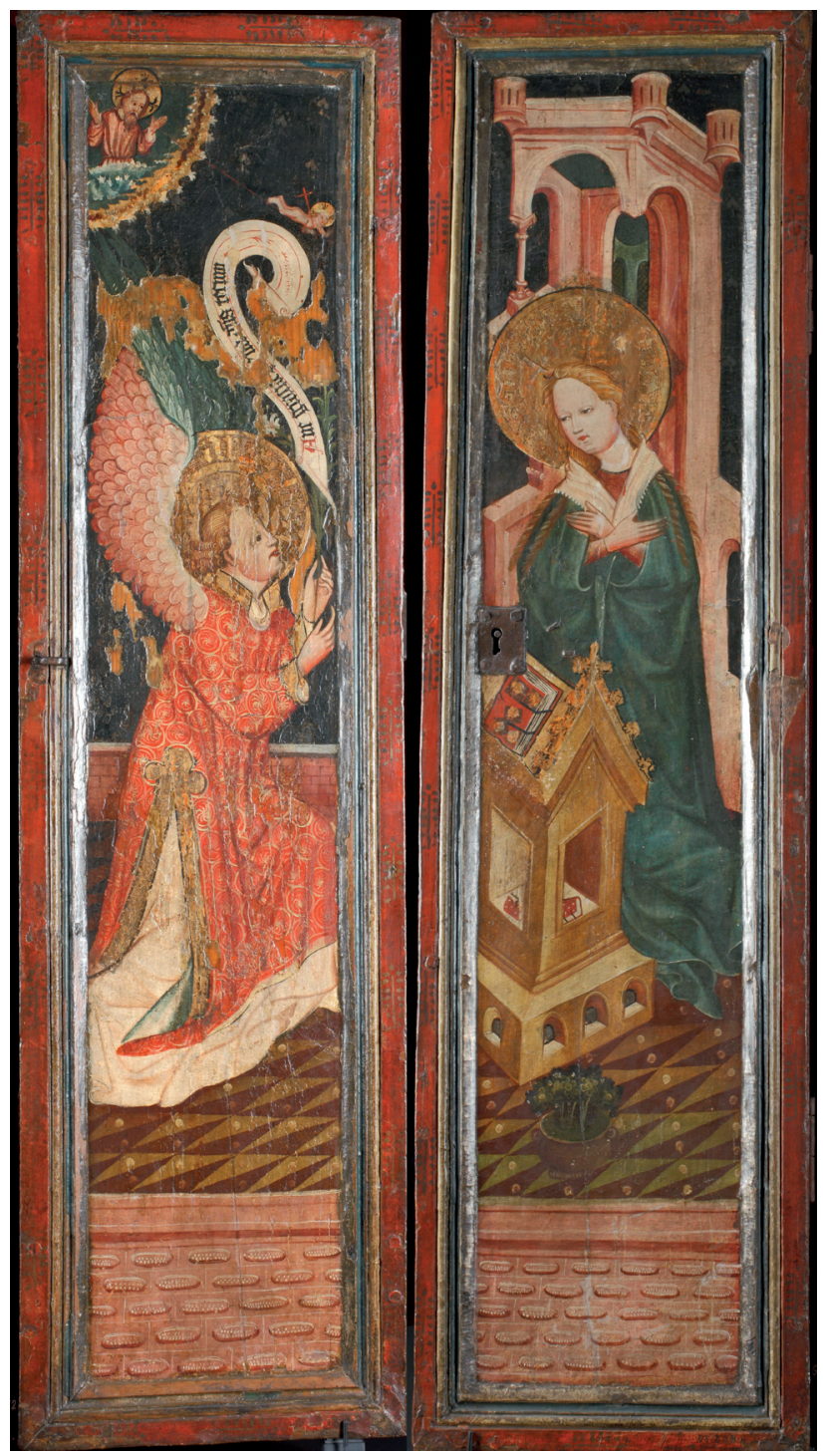

Fig. 8. The so-called 'small' Friedberg altarpiece,

Middle Rhine (probably Frankfurt), c. I325/50 (sculpture) and c. I420 (shrine), $78.5 \times 34.5 \times 25.5 \mathrm{~cm}$ (sculpture), $120 \times 240 \mathrm{~cm}$ (shrine when opened), Hessisches Landesmuseum Darmstadt, Inv. GK 2, closed,

(C) Hessisches Landesmuseum Darmstadt, Foto: Wolfgang Fuhrmannek. 


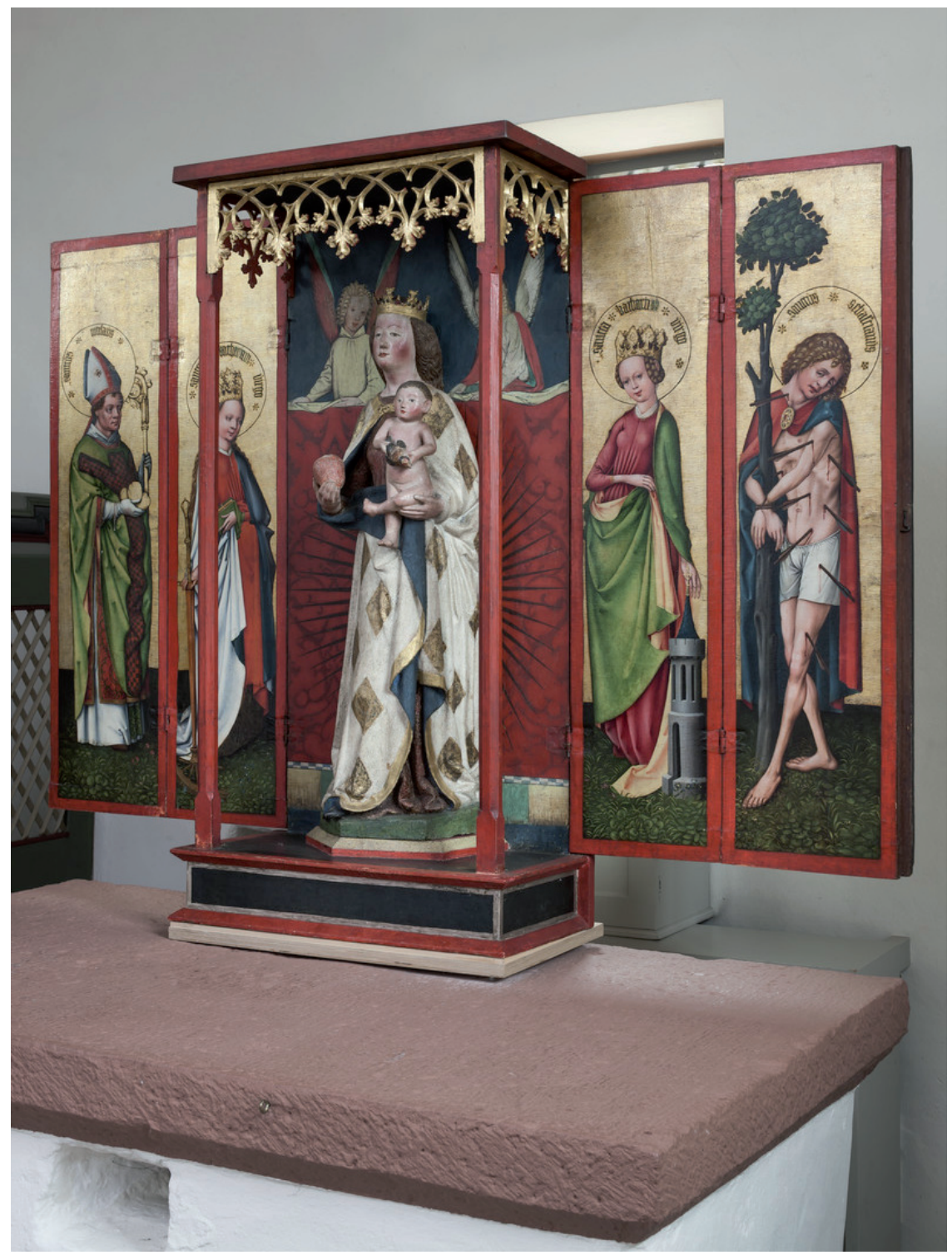

Fig. 9. Darsberg altarpiece, Middle Rhine, c. I460, IO5 X $33 \times 25 \mathrm{~cm}$ (sculpture), I4I X 60 × $30 \mathrm{~cm}$ (shrine), I24 X $30 \mathrm{~cm}$ (wings), chapel of Darsberg, Neckarsteinach, opened (C) Bildarchiv Foto Marburg/Christian Stein. 


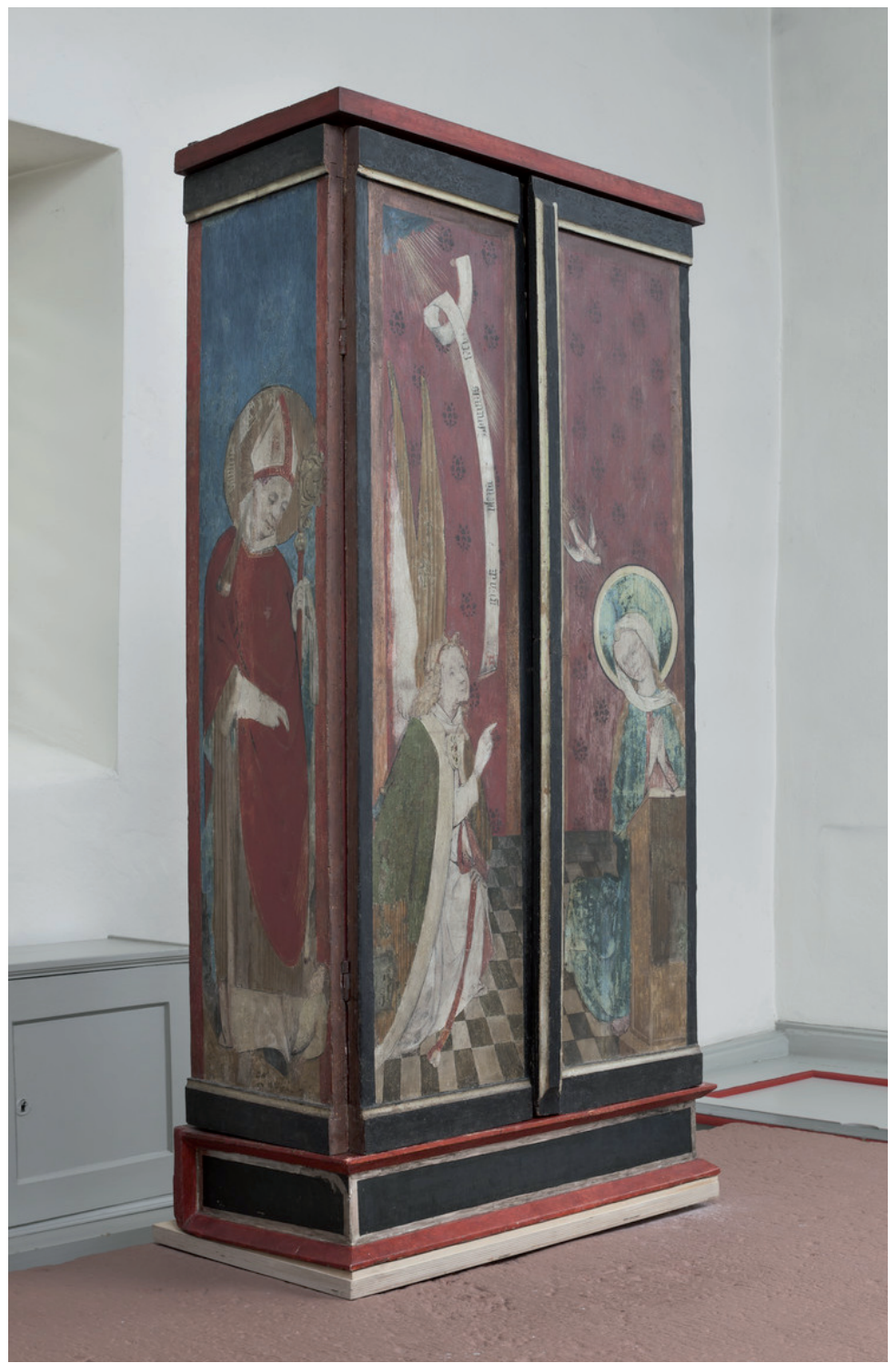

Fig. Io. Darsberg altarpiece, Middle Rhine, $c$. I460, IO5 X $33 \times 25 \mathrm{~cm}$ (sculpture), I4I X $60 \times 30 \mathrm{~cm}$ (shrine), I24 X $30 \mathrm{~cm}$ (wings), chapel of Darsberg, Neckarsteinach, closed (C) Bildarchiv Foto Marburg/Christian Stein. 